\title{
SYNTHESIS AND ANALYSIS OF ZINC METHIONINE, ZINC GLYCINE, COPPER LEUCINE, AND COPPER GLYCINE COMPLEXES USING ATOMIC ABSORPTION SPECTROPHOTOMETRY
}

\author{
SEKAR ALINDA NASTITI, HARMITA*, CATUR JATMIKA \\ Department of Pharmacy, Faculty of Pharmacy, Universitas Indonesia, Depok 16424, Indonesia. Email: igakadeharmita@gmail.com
} Received: 11 June 2018, Revised and Accepted: 08 November 2018

\section{ABSTRACT}

Objective: The aim of this study was to perform metal-amino acid synthesis and to analyze the free and bonded mineral concentrations.

Methods: In this study, the synthesis of amino acid metal complexes was carried out by reacting free metal ions, derived from a water-soluble metal salt, with amino acids in a 1:2 molar ratio.

Results: The respective yields of this synthesis process were 95.38\%, 95.95\%, 76.31\%, and 93.91\% for zinc (Zn)-methionine (Zn(Met) 2 ), Zn-glycine $\left(\mathrm{Zn}(\mathrm{gli})_{2}\right)$, copper-leucine $\left(\mathrm{Cu}(\mathrm{leu})_{2}\right)$, and $\mathrm{Cu}$-glycine $\left(\mathrm{Cu}(\mathrm{gli})_{2}\right)$ complexes, respectively. The metal-amino acid complexes were then separated using column chromatography and further analyzed by atomic absorption spectrophotometry (AAS). The bonded metal concentrations of the $\mathrm{Zn}(\mathrm{Met})_{2}$, $\mathrm{Zn}(\mathrm{gli})_{2}, \mathrm{Cu}(\mathrm{leu})_{2}$, and $\mathrm{Cu}(\mathrm{gli})_{2}$ complexes were $189.32 \mathrm{mg} / \mathrm{g}, 353.78 \mathrm{mg} / \mathrm{g}, 180.89 \mathrm{mg} / \mathrm{g}$, and $275.11 \mathrm{mg} / \mathrm{g}$, respectively. The free metal concentrations of the $\mathrm{Zn}(\mathrm{Met})_{2}, \mathrm{Zn}(\mathrm{glii})_{2}, \mathrm{Cu}(\mathrm{leu})_{2}$, and Cu(gli) ${ }_{2}$ complexes were $13.57 \mathrm{mg} / \mathrm{g}, 12.92 \mathrm{mg} / \mathrm{g}, 0.19 \mathrm{mg} / \mathrm{g}$, and $2.12 \mathrm{mg} / \mathrm{g}$, respectively.

Conclusion: In this study, $\mathrm{Zn}(\mathrm{Met})_{2}, \mathrm{Zn}(\mathrm{gli})_{2}, \mathrm{Cu}(\mathrm{leu})_{2}$, and $\mathrm{Cu}(\mathrm{gli})_{2}$ complexes were successfully formed and analyzed. The mineral concentration in each complex differed depending on the type of mineral and ligand.

Keywords: Amino acid complex, Atomic absorption spectrophotometry, Concentration, Metal.

(c) 2018 The Authors. Published by Innovare Academic Sciences Pvt Ltd. This is an open access article under the CC BY license (http://creativecommons. org/licenses/by/4. 0/) DOI: http://dx.doi.org/10.22159/ijap.2018.v10s1.86

\section{INTRODUCTION}

Humans require minerals to maintain certain biochemistry processes that are considered essential. Although minerals yield no energy in themselves, they are necessary for the functioning of numerous physiological activities inside the human body. Essential minerals occur in many forms and have various functions. Indeed, micronutrient deficiencies such as those that occur with mineral deficiencies are a major public health problem, with infants and pregnant woman particularly at risk [1].

Zinc $(\mathrm{Zn})$ is an essential element to many biological processes inside the body. Zn plays a role in the immune system, wound healing, and protein and DNA synthesis [2]. In addition to $\mathrm{Zn}$, copper (Cu) has important roles in the body, particularly for the blood and nervous system. $\mathrm{Cu}$ is considered necessary for bone formation, myelin sheaths in the nervous system, and the absorption of iron [1].

Deficiencies of essential minerals can cause various diseases or disorders. A Zn deficiency can lead to disorders of the immune, digestive, and integumentary system [2], while a $\mathrm{Cu}$ deficiency causes anemia, bone disorders, neonatal ataxia, depigmentation, and the abnormal growth of hair [1].

Mineral deficiencies can be caused by many different conditions such as: Not consuming enough of the foods that contain these essential minerals; diseases, such as diarrhea, that cause a massive loss of minerals; increased urine excretion due to diabetes; malabsorption; and an increased demand for minerals [2].

The free forms of minerals and mineral salts typically have low bioavailability [3]. However, the bioavailability of minerals can be enhanced by producing mineral complexes that are bonded to soluble organic compounds of low molecular weight, such as amino acids and peptides [4].
Previous studies have reported that making mineral-amino acid complexes enhances mineral bioavailability [5]. Furthermore, animal studies have also shown that the plasma concentrations of minerals are higher if administered in the organic form (i.e., as a metal-amino acid complex) than in the inorganic form [6].

Currently, mineral-amino acid complex supplements are widely available for both human and animal consumption. However, research regarding mineral-amino acid complexes has been limited in Indonesia. Existing research regarding mineral-amino acid complexes does not provide specific data regarding the concentration of free minerals and minerals bonded to the amino acids. Consequently, the aim of this study, conducted at the Central Drug, Food, and Cosmetic Quality Testing Laboratory of the Pharmacology faculty at the University of Indonesia (January-May 2017), was to perform metal-amino acid synthesis and to analyze the free and bonded mineral concentrations.

Complexes were synthesized using an existing method where metalamino acid complexes were produced by synthesizing mineral salts with amino acids, followed by crystallization. The synthesized complexes were then analyzed using Fourier-transform infrared (FTIR) spectrophotometry to observe the movement of amino acid clusters before and after complex synthesis. Before determining the concentrations of free and bonded minerals, separation was performed by ion exchange using adsorbent resin. Tokalioglu et al. conducted the separation of metal-amino acid complexes using resin to separate the metal ions from the organic materials [7]. Free and bonded mineral concentrations were then determined using atomic absorption spectrophotometry (AAS).

\section{METHODS}

The tools utilized for this analysis included AAS (Shimadzu A-6300, Japan), FTIR (Shimadzu 8400), Zn Hollow Cathode Lamp (Hamamatsu Photonics K.K, Japan), Cu Hollow Cathode Lamp (Hamamatsu Photonics 
K.K, Japan), MVU-1A (Shimadzu, Japan), an oven, hotplate, desiccator, analytical balance, micropipettes, volumetric pipettes, rubber balloons, Whatman filter paper no. 45, column, separatory funnel, and glass tools.

The various materials used included $\mathrm{Zn}$ and $\mathrm{Cu}$ in their free form (i.e., not bonded to other compounds) and $\mathrm{Zn}$-methionine $\left(\mathrm{Zn}(\mathrm{Met})_{2}\right)$, Zn-glycine $\left(\mathrm{Zn}(\mathrm{gli})_{2}\right)$, Cu-leucine $\left(\mathrm{Cu}(\mathrm{leu})_{2}\right)$, and $\mathrm{Cu}$-glycine $\left(\mathrm{Cu}(\mathrm{gli})_{2}\right)$ complex synthesis materials.

The chemicals used in this study were obtained from Merck and included $\mathrm{Zn}$ standard solution $1000 \mathrm{mg} / \mathrm{L}, \mathrm{Cu}$ standard solution $1000 \mathrm{mg} / \mathrm{L}$, methionine, glycine, leucine, $\mathrm{HNO}_{3}$ p.a, $\mathrm{ZnSO}_{4} \cdot 7 \mathrm{H}_{2} \mathrm{O}$, acetone, $\mathrm{Zn}\left(\mathrm{CH}_{3} \mathrm{COOH}\right)_{2} \mathrm{Cu}\left(\mathrm{NO}_{3}\right)_{2} \cdot 3 \mathrm{H}_{2} \mathrm{O}, \mathrm{CuSO}_{4} \cdot 5 \mathrm{H}_{2} \mathrm{O}, \mathrm{NaOH}$, ethanol, $\mathrm{HCl}$, methanol, and $\mathrm{KBr}$

\section{Calibration curve for $\mathrm{Zn}$ solution production}

The calibration curve for the $\mathrm{Zn}$ solution was made by pipetting $10 \mathrm{~mL}$ of $1000 \mathrm{mg} / \mathrm{L} \mathrm{Zn}$ standard solution into a $100 \mathrm{~mL}$ volumetric flask until $100 \mathrm{mg} / \mathrm{L}$ of Zn solution was reached. Then, $50 \mathrm{~mL}$ of $100 \mathrm{mg} / \mathrm{L} \mathrm{Zn}$ standard solution was pipetted into a $500 \mathrm{~mL}$ volumetric flask until $10 \mathrm{mg} / \mathrm{mL}$ of $\mathrm{Zn}$ solution was reached. Aliquots $(0.5,1.0,2.0,5.0,10$, and $20 \mathrm{~mL}$ ) of $10 \mathrm{mg} / \mathrm{L} \mathrm{Zn} \mathrm{standard} \mathrm{solution} \mathrm{were} \mathrm{then} \mathrm{pipetted} \mathrm{into}$ $100 \mathrm{~mL}$ volumetric flasks until $0.05 \mathrm{mg} / \mathrm{L}, 0.1 \mathrm{mg} / \mathrm{L}, 0.2 \mathrm{mg} / \mathrm{L}, 0.5 \mathrm{mg} / \mathrm{L}$, $1.0 \mathrm{mg} / \mathrm{L}$, and $2.0 \mathrm{mg} / \mathrm{L}$ of Zn metal concentrations, respectively, were reached.

\section{Calibration curve for $\mathrm{Cu}$ solution production}

The calibration curve for the $\mathrm{Cu}$ solution was made by pipetting $0.5 \mathrm{~mL}$ of $1000 \mathrm{mg} / \mathrm{L} \mathrm{Cu}$ standard solution into a $50 \mathrm{~mL}$ volumetric flask until $10 \mathrm{mg} / \mathrm{L}$ of $\mathrm{Cu}$ solution was reached. Aliquots $(0.5,2.0,4.0,6.0,8.0$, and $10 \mathrm{~mL}$ ) of $10 \mathrm{mg} / \mathrm{L} \mathrm{Cu}$ standard solution were then pipetted into $50 \mathrm{~mL}$ volumetric flasks until $0.1 \mathrm{mg} / \mathrm{L}, 0.4 \mathrm{mg} / \mathrm{L}, 0.8 \mathrm{mg} / \mathrm{L}, 1.2 \mathrm{mg} / \mathrm{L}$, $1.6 \mathrm{mg} / \mathrm{L}$, and $2.0 \mathrm{mg} / \mathrm{L}$ of $\mathrm{Cu}$ metal concentrations, respectively, were reached.

\section{Synthesis of $\mathrm{Zn}(\mathrm{Met})_{2}$ complexes}

To synthesize the $\mathrm{Zn}$ (Met) ${ }_{2}$ complexes, $250 \mathrm{mg}$ methionine $(1.75 \mathrm{mmol})$ was diluted into $8 \mathrm{~mL} \mathrm{NaOH}(1 \mathrm{~mol} / \mathrm{L})$ by stirring for $30 \mathrm{~min}$. Zn sulfate heptahydrate $(250 \mathrm{mg} ; 0.875 \mathrm{mmol}$ ) was then added while stirring until a white sediment was formed. This precipitation product was then filtered and dried under vacuum at $100^{\circ} \mathrm{C}$ for $2 \mathrm{~h}$. The white sediment obtained represented the $\mathrm{Zn}(\mathrm{Met})_{2}$ complex.

\section{Synthesis of Zn(gli) $)_{2}$ complexes}

To synthesize the $\mathrm{Zn}(\mathrm{gli})_{2}$ complexes, $150 \mathrm{mg}$ glycine solution ( $2 \mathrm{mmol}$ ) in $5 \mathrm{~mL}$ distilled water was added into $220 \mathrm{mg} \mathrm{Zn}$ acetate solution $\left(\mathrm{Zn}\left(\mathrm{CH}_{3} \mathrm{COOH}\right)_{2}\right)(1 \mathrm{mmol})$ in $2 \mathrm{~mL}$ distilled water. The mixture was then heated at $100^{\circ} \mathrm{C}$ for $2 \mathrm{~h}$ while stirring. The solution was then evaporated at low temperature until a white sediment was produced and then dried.

\section{Synthesis of $\mathrm{Cu}(\mathrm{leu})_{2}$ complexes}

To synthesize the $\mathrm{Cu}(\mathrm{leu})_{2}$ complexes, $131 \mathrm{mg}$ leucine $(1 \mathrm{mmol})$ was diluted into $10 \mathrm{~mL}$ distilled water. Into that solution, we dropped $0.33 \mathrm{~mL}$ of $15 \% \mathrm{NaOH}$. The solution was then stirred for $20 \mathrm{~min}$, followed by the addition of $125 \mathrm{mg} \mathrm{Cu}\left(\mathrm{SO}_{4}\right) \cdot 7 \mathrm{H}_{2} \mathrm{O}$ solution $(0.5 \mathrm{mmol})$ in $2 \mathrm{~mL}$ distilled water. The solution was then stirred for $1 \mathrm{~h}$ until a blue sediment was formed. The sediment was then filtered and dried. The light blue sediment powder obtained represented the $\mathrm{Cu}(\mathrm{leu})_{2}$ complex.

\section{Synthesis of $\mathrm{Cu}(\mathrm{gli})_{2}$ complexes}

First, $2 \mathrm{mmol}$ glycine $(150 \mathrm{mg}$ ) was diluted into $20 \mathrm{~mL}$ of distilled water until it was dissolved completely, followed by the addition of $0.33 \mathrm{~mL}$ of $30 \% \mathrm{NaOH}$. The solution was stirred for $20 \mathrm{~min}$, followed by the addition of $1 \mathrm{mmol}(241 \mathrm{mg})$ of $\mathrm{Cu}\left(\mathrm{NO}_{3}\right)_{2} \cdot 3 \mathrm{H}_{2} \mathrm{O}$ in $2 \mathrm{~mL}$ of distilled water. The mixture was then stirred for $1 \mathrm{~h}$, after which ethanol was added while stirring until a sediment was formed. The sediment was then filtered. The blue sediment obtained represented the $\mathrm{Cu}(\mathrm{gli})_{2}$ complex.

\section{Determination of water content}

Determination of water content of complexes was conducted using a drying shrinkage method. The formed complexes were weighed and placed in an oven at $105^{\circ} \mathrm{C}$ for $2 \mathrm{~h}$. The dried complexes were then reweighed until a stabilized weight was achieved.

\section{Complex formation identification using FTIR}

To identify the formation of the metal-amino acid complexes, FTIR spectrophotometry was used. Potassium Bromide (KBr) $(100 \mathrm{mg}$ dried powder) was used as the blank and baseline. Sample powder of the complexes (2 mg) was mixed with $98 \mathrm{mg} \mathrm{KBr}$ powder and crushed using a jade mortar and pestle until homogenous. The powder mixture was then put into a disc and set into the FTIR machine. Absorption spectrum was obtained at a wavelength of $400-4000 \mathrm{~cm}^{-1}$.

\section{Separation of free and bonded metals in the complexes}

Separation was performed using the adsorption column method on adsorbent resin. The separation principle was to hold the metals bonded to amino acids on the adsorbent resin, while the free metals would be dissolved. Before the separation, the column was conditioned by washing successively with methanol, distilled water, $\mathrm{HNO}_{3} 1 \mathrm{M}$ in acetone, distilled water, $\mathrm{NaOH} 1 \mathrm{M}$, and distilled water again [7]. The complex samples (50 mg) were dissolved in $10 \mathrm{~mL}$ distilled water and put into the resin-containing column. The eluate product was metal ions in their free form. The eluate was then diluted and analyzed by AAS.

\section{Sample destruction}

Complexes $\left(50 \mathrm{mg}\right.$ ) were destroyed using $5 \mathrm{~mL} \mathrm{HNO} \mathrm{H}_{3(\mathrm{p})}$ and heating at $100^{\circ} \mathrm{C}$ until the solution becomes clear and white smoke formed, indicating that the destruction had completed.

\section{Sample concentration determination}

The analytical conditions for determining $\mathrm{Zn}$ and $\mathrm{Cu}$ concentrations using the atomic absorption spectrophotometer are shown in Table 1. Samples from the column included the free metals that were directly analyzed without destruction. The other samples were metal-amino acid complexes that were destroyed using $\mathrm{HNO}_{3(\mathrm{p})}$. Absorption outcomes were then plotted into a calibration curve.

\section{RESULTS AND DISCUSSION}

\section{$\mathrm{Zn}$ (Met) ${ }_{2}$ complex synthesis results}

The synthesis of the metal-amino acid complexes was performed by reacting amino acids with metal salts in a 1:2 ratio. For the $\mathrm{Zn}(\mathrm{Met})_{2}$, $\mathrm{Cu}(\mathrm{leu})_{2}$, and $\mathrm{Cu}(\mathrm{gli})_{2}$ complexes, $\mathrm{NaOH}$ acted as a deprotonator of $\mathrm{H}^{+}$ protons at the $\mathrm{OH}$ group in the amino acid. For the $\mathrm{Zn}(\mathrm{gli})_{2}$ complexes, $\mathrm{Zn}$ acetate was used for this purpose. Anion acetate acted as a weak acid, deprotonating the $\mathrm{H}^{+}$ion of the $\mathrm{OH}$ group. Complexes consisted of a white powder for the $\mathrm{Zn}(\mathrm{Met})_{2}$ and $\mathrm{Zn}(\mathrm{gli})_{2}$ complexes, while they were a blue powder for $\mathrm{Cu}(\mathrm{leu})_{2}$ and $\mathrm{Cu}(\mathrm{gli})_{2}$ complexes. The yield of the synthesis was $95.38 \%, 95.95 \%, 76.31 \%$, and $93.91 \%$ for the $\mathrm{Zn}(\mathrm{Met})_{2}$, $\mathrm{Zn}(\mathrm{gli})_{2}, \mathrm{Cu}(\mathrm{leu})_{2}$, and $\mathrm{Cu}(\mathrm{gli})_{2}$ complexes, respectively. The respective yields of this synthesis process were for $\mathrm{Zn}(\mathrm{Met})_{2}, \mathrm{Zn}(\mathrm{gli})_{2}, \mathrm{Cu}(\mathrm{leu})_{2}$, and $\mathrm{Cu}(\mathrm{gli})_{2}$ complexes.

\section{Structure identification using FTIR}

Structure identification using FTIR showed that there was a significant shift between the amino acid and metal-amino acid complexes. The

Table 1: Conditions for $\mathrm{Zn}$ and $\mathrm{Cu}$ analysis

\begin{tabular}{lll}
\hline Measurement & Zn & Cu \\
\hline Wavelength & $213.9 \mathrm{~nm}$ & $324.8 \mathrm{~nm}$ \\
Slit width & $1 \mathrm{~nm}$ & $0.7 \mathrm{~nm}$ \\
Light current & $5 \mathrm{~mA}$ & $6 \mathrm{~mA}$ \\
Burner height & 7 & 7 \\
Gas flow rate & $1.8 \mathrm{~L} / \mathrm{min}$ & $1.8 \mathrm{~L} / \mathrm{min}$ \\
Air flow rate & $15 \mathrm{~L} / \mathrm{min}$ & $15 \mathrm{~L} / \mathrm{min}$ \\
\hline
\end{tabular}

Zn: Zinc, Cu: Copper 
most noticeable difference was in the $-\mathrm{OH}$ carboxylic groups of amino acids that were no longer visible in the complex infrared spectrum. This is due to the separation of the $\mathrm{O}$ and $\mathrm{H}$ bond, which was replaced by a covalent bond between the 0 atom and the metal [8]. In the complex spectrum, the symmetric and asymmetric stretching vibration of $\mathrm{NH}_{2}$ was also observed, indicating the interaction between the amine and the metal groups [9].

Tables 2-5 are comparison tables of the FTIR results between amino acids and the complexes produced:

\section{Determination of water content}

Based on our calculations, the water content in the Zn(Met) ${ }_{2}$ complex was $0.90 \%$. In contrast, the water content in the $\mathrm{Zn}(\mathrm{gli})_{2}$ complex was $2.38 \%$. The water content in the $\mathrm{Cu}(\mathrm{leu})_{2}$ complex was $2.30 \%$, while in the $\mathrm{Cu}(\mathrm{gli})_{2}$ complex, it was $1.87 \%$.

\section{Standard solution making}

The $\mathrm{Zn}$ standard solution was obtained by dissolving $211 \mathrm{mg}$ heptahydrate $\mathrm{Zn}$ sulfate powder into $100 \mathrm{~mL}$ distilled water until a $500 \mu \mathrm{g} / \mathrm{mL} \mathrm{Zn}$ standard solution was achieved. This solution was then

Table 2: Comparison of infrared spectrum between methionine and $\mathrm{Zn}$ (Met) ${ }_{2}$ complexes

\begin{tabular}{lll}
\hline Group & Methionine & Zn (Met) \\
\hline $\mathrm{N}-\mathrm{H}$ & - & 3306 and $3261 \mathrm{~cm}^{-1}$ \\
$\mathrm{O}-\mathrm{H}$ & $3178-2405 \mathrm{~cm}^{-1}$ & - \\
$\mathrm{C}-\mathrm{H}$ & - & $2916 \mathrm{~cm}^{-1}$ \\
$\mathrm{C}=\mathrm{O}$ & $1581 \mathrm{~cm}^{-1}$ & $1606 \mathrm{~cm}^{-1}$ \\
$\mathrm{C}-\mathrm{O}$ & $1417 \mathrm{~cm}^{-1}$ & $1427 \mathrm{~cm}^{-1}$ \\
S-CH & $1242 \mathrm{~cm}^{-1}$ & $1244 \mathrm{~cm}^{-1}$ \\
\hline
\end{tabular}

Zn (Met) $)_{2}$ : Zinc-methionine

Table 3: Comparison of infrared spectrum between glycine and Zn (gli) $)_{2}$ complexes

\begin{tabular}{lll}
\hline Group & Glycine & Zn (gli) \\
\hline $\mathrm{N}-\mathrm{H}$ & - & $3271 \mathrm{~cm}^{-1}$ \\
$\mathrm{O}-\mathrm{H}$ & $3334-2175 \mathrm{~cm}^{-1}$ & - \\
$\mathrm{C}-\mathrm{H}$ & - & $2941 \mathrm{~cm}^{-1}$ \\
$\mathrm{C}=\mathrm{O}$ & $1697 \mathrm{~cm}^{-1}$ & $1589 \mathrm{~cm}^{-1}$ \\
$\mathrm{C}-\mathrm{O}$ & $1422 \mathrm{~cm}^{-1}$ & $1408 \mathrm{~cm}^{-1}$ \\
\hline Zn (gli) $:$ Zinc-glycine & &
\end{tabular}

Table 4: Comparison of infrared spectrum between leucine and $\mathrm{Cu}(\mathrm{leu})_{2}$ complexes

\begin{tabular}{lll}
\hline Group & Leucine & Cu (leu) \\
\hline $\mathrm{N}-\mathrm{H}$ & $3242,5 \mathrm{~cm}^{-1}$ & $3315 \& 3244 \mathrm{~cm}^{-1}$ \\
$\mathrm{O}-\mathrm{H}$ & $3109-2392 \mathrm{~cm}^{-1}$ & - \\
$\mathrm{C}-\mathrm{H}$ & $2951 \mathrm{~cm}^{-1}$ & $2958 \mathrm{~cm}^{-1}$ \\
$\mathrm{C}=\mathrm{O}$ & $1617 \mathrm{~cm}^{-1}$ & $1619 \mathrm{~cm}^{-1}$ \\
$\mathrm{C}-\mathrm{NH}$ & $1566 \mathrm{~cm}^{-1}$ & $1567 \mathrm{~cm}^{-1}$ \\
C-O & $1466 \mathrm{~cm}^{-1}$ & $1468 \mathrm{~cm}^{-1}$ \\
\hline
\end{tabular}

$\mathrm{Cu}(\mathrm{leu})_{2}$ : Copper-leucine

Table 5: Comparison of infrared spectrum between glycine and $\mathrm{Cu}(\mathrm{gli})_{2}$ complexes

\begin{tabular}{lll}
\hline Group & Glycine & Cu (gli) \\
\hline $\mathrm{N}-\mathrm{H}$ & - & 3337 and $3292 \mathrm{~cm}^{-1}$ \\
$\mathrm{O}-\mathrm{H}$ & $3334-2175 \mathrm{~cm}^{-1}$ & - \\
$\mathrm{C}-\mathrm{H}$ & - & $2955 \mathrm{~cm}^{-1}$ \\
$\mathrm{C}=\mathrm{O}$ & $1697 \mathrm{~cm}^{-1}$ & $1672 \mathrm{~cm}^{-1}$ \\
$\mathrm{C}-\mathrm{O}$ & $1422 \mathrm{~cm}^{-1}$ & $1400 \mathrm{~cm}^{-1}$ \\
\hline
\end{tabular}

diluted until $0.1,0.2,0.4,0.6,0.8$, and $1.0 \mu \mathrm{g} / \mathrm{mL}$ standard solutions were obtained.

The $\mathrm{Cu}$ standard solution was obtained by diluting $1000 \mu \mathrm{g} / \mathrm{mL} \mathrm{Cu}$ standard solution in demineralized water until $0.1,0.4,0.8,1.2,1.6$, and $2.0 \mu \mathrm{g} / \mathrm{mL}$ standard solutions were obtained.

The concentration range of the calibrated curve was then adjusted until the metal concentration in the sample was in range. Great precision was required in the making of standard solutions because of the small concentrations, which were in part per million (ppm).

\section{Sample preparation}

Before metal concentration analysis of the complexes was performed, the samples were first prepared. Each complex was prepared in two ways: Through separation by column chromatography then directly analyzed and by wet destruction.

\section{Separation by column chromatography}

For column chromatography separation, complexes were dissolved into $10 \mathrm{~mL}$ distilled water and then passed through column with a $1.5 \mathrm{~cm}$ diameter and height of $7.5 \mathrm{~cm}$. The adsorbent resin was used represented resin that had been washed with methanol, $\mathrm{HCl} 1 \mathrm{M}$ in acetone, $\mathrm{NaOH} 1 \mathrm{M}$, and Aquadest. Results from the separation using column chromatography indicated that the free metal was not bonded to amino acids. Free metals not bonded to amino acids represented the first eluate of the samples passed through the column [7]. After separation by column chromatography, the eluate was directly analyzed using AAS, as the metal was already in ionized form and further destruction was not needed. The effluent was used to analyze the free metals in $\mathrm{Zn}(\mathrm{Met})_{2}, \mathrm{Zn}(\mathrm{gli})_{2}$, and $\mathrm{Cu}(\mathrm{leu})_{2}$ complexes and the effluent was diluted by 100 dilution factor. However, the $\mathrm{Cu}(\mathrm{leu})_{2}$ effluent did not dilute to meet the calibration curve; this was because the diluted effluent had a very low concentration and could not be detected.

\section{Wet destruction}

Each complex was destroyed using the wet destruction method with an $\mathrm{HNO}_{3(\mathrm{p})}$ solution. This method aimed to break the amino acid and metal bonds to produce the free inorganic ions [10-13]. Each sample, weighing as much as $\pm 50 \mathrm{mg}$, was destroyed using $5 \mathrm{~mL} \mathrm{HNO}_{3(\mathrm{p})}$. Sample destruction produced a clear solution with a different color for each sample. These results indicated that the destruction had been completed and all constituents were completely dissolved, or the destruction of the organic substances had progressed successfully [14]. After sample destruction, samples were diluted to meet the calibration curve range.

\section{Concentration determination}

According to our analysis, the metal concentration in the $\mathrm{Zn}(\mathrm{Met})$ complex was $202.89 \mathrm{mg} / \mathrm{g}$, with $13.57 \mathrm{mg} / \mathrm{g}$ free metal. The metal concentration in the $\mathrm{Zn}$ (gli) $)_{2}$ complex was $366.70 \mathrm{mg} / \mathrm{g}$, with $12.92 \mathrm{mg} / \mathrm{g}$ free metal. The metal concentration in the $\mathrm{Cu}(\mathrm{leu})_{2}$ complex was $181.08 \mathrm{mg} / \mathrm{g}$, with $0.19 \mathrm{mg} / \mathrm{g}$ free metal, while that of the $\mathrm{Cu}(\mathrm{gli})_{2}$ complex was $277.23 \mathrm{mg} / \mathrm{g}$, with $2.12 \mathrm{mg} / \mathrm{g}$ free metal.

For the complexes, the analyzed metal concentration was the concentration of all metals in the complexes because there were residual metal ions that did not bond to the amino acid. The total metal concentration consisted of metal that was bonded to the amino acid and free metal that did not bond to the amino acid.

To determine the amount of metal that was bonded to the amino acid, the amount of free metal concentration was subtracted from the total metal concentration. The presence of free metal in the complexes was due to complexes that were not washed, so residual metal ions remained. Based on our calculation, the bonded metal concentration of the $\mathrm{Zn}(\text { Met })_{2}, \mathrm{Zn}(\mathrm{gli})_{2}, \mathrm{Cu}(\mathrm{leu})_{2}$, and $\mathrm{Cu}(\mathrm{gli})_{2}$ complexes were $189.32 \mathrm{mg} / \mathrm{g}$, $353.78 \mathrm{mg} / \mathrm{g}, 180.89 \mathrm{mg} / \mathrm{g}$, and $275.11 \mathrm{mg} / \mathrm{g}$, respectively. 


\section{CONCLUSION}

In this study, $\mathrm{Zn}(\mathrm{Met})_{2}, \mathrm{Zn}(\mathrm{gli})_{2}, \mathrm{Cu}(\mathrm{leu})_{2}$, and $\mathrm{Cu}(\mathrm{gli})_{2}$ complexes were successfully formed and analyzed. The mineral concentration in each complex differed depending on the type of mineral and ligand.

\section{CONFLICTS OF INTEREST}

All authors have none to declare.

\section{REFERENCES}

1. Soetan K, Oloaiya C, Oyewole O. The importance of mineral elements for humans, domestic animals and plants: A review. Afr J Food Sci 2010;4:200-22.

2. Corbo MD, Lam J. Zinc deficiency and its management in the pediatric population: A literature review and proposed etiologic classification. J Am Acad Dermatol 2013;69:616-240.

3. Fredlund K, Isaksson M, Rossander-Hulthén L, Almgren A, Sandberg AS. Absorption of zinc and retention of calcium: Dose-dependent inhibition by phytate. J Trace Elem Med Biol 2006;20:49-57.

4. Wang C, Li B, Wang B, Xie N. Degradation and antioxidant activities of peptides and zinc-peptide complexes during in vitro gastrointestinal digestion. Food Chem 2015;173:733-40.

5. Miquel E, Farre R. Effects and future trends of casein phosphopeptides on zinc bioavailability. Trends Food Sci Technol 2007;18:139-43.

6. Pal DT, Gowda NK, Prasad CS, Amarnath R, Bharadwaj U, Suresh Babu G, et al. Effect of copper- and zinc-methionine supplementation on bioavailability, mineral status and tissue concentrations of copper and zinc in ewes. J Trace Elem Med Biol 2010;24:89-94.

7. Tokalioglu S, Elci L, Kartal S. Speciation and determination of heavy metals in lake waters by atomic absorption spectrometry after sorption on amberlite XAD-16 resin. Anal Sci 2000;16:1169-74.

8. Ashmead H. The Roles of Amino Acid Chelates in Animal Nutrition. USA: Noyes Publications; 1993

9. Berestova T, Kuzina L, Amineva N, Faizrakhmanov I, Massalimov I, Mustafin A. ATR-FTIR spectroscopic investigation of the cis- and trans-bis-( $\alpha$-amino acids) copper(II) complexed. J Mol Struct 2017;1137:260-6.

10. Murtini ES, Hastuti R, Gunawan DP. The Effect of Destruction on the Determination of $\mathrm{Cu}$ (II) Levels in Well Water, Sea Water and Chrome Coating Wastewater Using AAS. Undergraduate Thesis, Semarang: UNDIP; 2009.

11. Ayaprakash R, Saroj KS, Hemalatha S, Easwaramoorthy D. Synthesis, characterizatioon, quantitative structure-activity relationship, docking, antibacterial activity, and brine shrimp lethal studies on L-phenylalanine schiff bases. Asian J Pharm Clin Res 2016;9:203-8.

12. Mohanambal D, Arulantony S. Synthesis, spectral characterization of schiff base complexes based on pyrimidine moiety with molecular docking with biomolecules. Asian J Pharm Clin Res 2018;11:93-8.

13. Jalhan S, Jindal A, Hemraj GA. Synthesis, biological activities and chemistry of thiadiazole derivatives and schiff bases. Asian J Pharm Clin Res 2012;5:199-8.

14. Raimon G. Comparison of Wet and Dry Digestion Methods by Atomic Absorption Spectrophotometry. National Analytical Chemistry Workshop. Yogyakarta: Jaringan Kerjasama Kimia Analitik; 1993. 